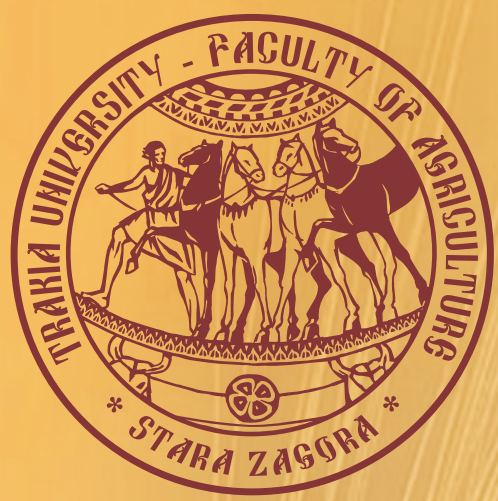

ISSN $1313-8820$ (print)

ISSN 1314 - 412X (online)

Volume 9 , Number 4

December 2017

\title{
AGRICULTURAL
}

\section{SCIENCE AND TECHNOLOGY}

\section{7}

An International Journal Published by Faculty of Agriculture, Trakia University, Stara Zagora, Bulgaria 


\section{Editor-in-Chief}

Georgi Petkov

Faculty of Agriculture

Trakia University, Stara Zagora

Bulgaria

E-mail: gpetkov@af.uni.sz.bg

\section{Co-Editor-in-Chief}

Dimitar Panayotov

Faculty of Agriculture

Trakia University, Stara Zagora

Bulgaria

\section{Editors and Sections}

\section{Genetics and Breeding}

Tsanko Yablanski (Bulgaria)

Atanas Atanasov (Bulgaria)

Svetlana Georgieva (Bulgaria)

Nikolay Tsenov (Bulgaria)

Max Rothschild (USA)

Ihsan Soysal (Turkey)

Horia Grosu (Romania)

Stoicho Metodiev (Bulgaria)

Bojin Bojinov (Bulgaria)

\section{Nutrition and Physiology}

Nikolai Todorov (Bulgaria)

Peter Surai (UK)

Ivan Varlyakov (Bulgaria)

George Zervas (Greece)

Vasil Pirgozliev (UK)

\section{Production Systems}

Radoslav Slavov (Bulgaria)

Dimitar Pavlov (Bulgaria)

Bogdan Szostak (Poland)

Banko Banev (Bulgaria)

Georgy Zhelyazkov (Bulgaria)

\section{Agriculture and Environment}

Martin Banov (Bulgaria)

Peter Cornish (Australia)

Vladislav Popov (Bulgaria)

Tarek Moussa (Egypt)

\section{Product Quality and Safety}

Stefan Denev (Bulgaria)

Vasil Atanasov (Bulgaria)

Roumiana Tsenkova (Japan)

\section{English Editor}

Yanka Ivanova (Bulgaria)
Scope and policy of the journal

Agricultural Science and Technology /AST/

- an International Scientific Journal of Agricultural and Technology Sciences is published in English in one volume of 4 issues per year, as a printed journal and in electronic form. The policy of the journal is to publish original papers, reviews and short communications covering the aspects of agriculture related with life sciences and modern technologies. It will offer opportunities to address the global needs relating to food and environment, health, exploit the technology to provide innovative products and sustainable development. Papers will be considered in aspects of both fundamental and applied science in the areas of Genetics and Breeding, Nutrition and Physiology, Production Systems, Agriculture and Environment and Product Quality and Safety. Other categories closely related to the above topics could be considered by the editors. The detailed information of the journal is available at the website. Proceedings of scientific meetings and conference reports will be considered for special issues.

\section{Submission of Manuscripts}

There are no submission / handling / publication charges.

All manuscripts written in English should be submitted as MS-Word file attachments via e-mail to editoffice@agriscitech.eu. Manuscripts must be prepared strictly in accordance with the detailed instructions for authors at the website

www.agriscitech.eu and the instructions on the last page of the journal. For each manuscript the signatures of all authors are needed confirming their consent to publish it and to nominate on author for correspondence.

They have to be presented by a submission letter signed by all authors. The form of the submission letter is available upon from request from the Technical Assistance or could be downloaded from the website of the journal. Manuscripts submitted to this journal are considered if they have submitted only to it, they have not been published already, nor are they under consideration for publication in press elsewhere. All manuscripts are subject to editorial review and the editors reserve the right to improve style and return the paper for rewriting to the authors, if necessary. The editorial board reserves rights to reject manuscripts based on priorities and space availability in the journal.

The journal is committed to respect high standards of ethics in the editing and reviewing process and malpractice statement. Commitments of authors related to authorship are also very important for a high standard of ethics and publishing. We follow closely the Committee on Publication Ethics (COPE), http://publicationethics.org/resources/guid elines

The articles appearing in this journal are indexed and abstracted in: DOI, EBSCO Publishing Inc., AGRIS (FAO) and DOAJ.

The journal is accepted to be indexed with the support of a project № BG051P00013.3.05-0001 "Science and business" financed by Operational Programme "Human Resources Development" of EU. The title has been suggested to be included in SCOPUS (Elsevier) and Electronic Journals Submission Form (Thomson Reuters).

The journal is freely available without charge to the user or his/her institution. Users can read, download, copy, distribute, print, search, or link to the full texts of the articles, or use them for any other lawful purpose, without asking prior permission from the publisher or the author.

This issue is printed with the financial support by Contract No DNP 0521/20.12.2016, financed from Fund 'Scientific Research' grant Bulgarian scientific Periodicals.

\section{Address of Editorial office:}

Agricultural Science and Technology Faculty of Agriculture, Trakia University

Student's campus, 6000 Stara Zagora

Bulgaria

Telephone: +35942699330 $+35942699446$

www.agriscitech.eu

Technical Assistance:

Nely Tsvetanova

Telephone: +359 42699446

E-mail:editoffice@agriscitech.eu 


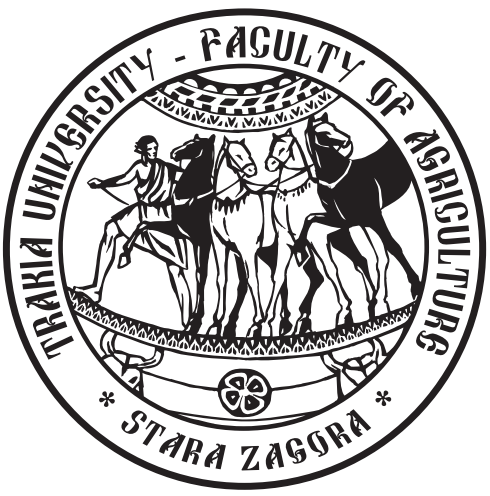

AGRICULTURAL

SCIENCE AND TECHNOLOGY

\section{7}

An International Journal Published by Faculty of Agriculture,

Trakia University, Stara Zagora, Bulgaria 


\title{
Evaluation of some technological properties of Caucasian ram wool
}

\author{
D. Pamukova ${ }^{1 *}$, G. Staykova², N. Stancheva², D. Panayotov \\ 'Department of Animal Science - Ruminant Animals and Dairy Science, Faculty of Agriculture,Trakia University, 6000 Stara Zagora, Bulgaria \\ ${ }^{2}$ Agricultural Institute, 3 Simeon Veliki, 9700 Shumen, Bulgaria
}

(Manuscript received 10 September 2017; accepted for publication 17 November 2017)

\begin{abstract}
The aim of the study was to establish the levels of the main selection traits which determine the technological wool production in the rams from the breed of Caucasian merino sheep. The study included a total of 126 rams at 18 months of age from Caucasian merino breed. To determine the fibre diameter, a total of 252 wool samples from two parts of the body (side and leg) were analyzed. For laboratory examination of staple length and crimp of wool, a total 36 wool samples (from the side and the leg) were studied. The rams from Caucasian breed had a very good topographic equality of fiber thickness and staple length. The average fiber diameter of the side was $21.98 \mu \mathrm{m}$ (with variation from $21.71 \mu \mathrm{m}$ to $22.30 \mu \mathrm{m}$ ) and the leg was $23.05 \mu \mathrm{m}$ (with variation from $22.76 \mu \mathrm{m}$ to $23.34 \mu \mathrm{m}$ ). The wool's fineness in the fleece was 64 's quality in $76.98 \%$ of the samples, which characterized it as a fine merino wool. The number of crimps per $1 \mathrm{~cm}$ in the rams was an average of $5.07 \mathrm{nrs}$. on the side and $4.46 \mathrm{nrs}$. on the leg and in the rams at 18 months of age $-5.26 \mathrm{nrs}$. and $4.82 \mathrm{nrs}$., respectively.
\end{abstract}

Keywords: Caucasian breed, merino wool, fibre diameter, staple length, crimp of wool

\section{Introduction}

The annual production of merino wool depends on the current market situation. The factors influencing demand are competition from other textile fibres (cotton and synthetic fibres), purchasing power of households, wool production efficiency, changes in consumer demands. Since 1990 that marked the peak in global grease wool produce (3 $350508 \mathrm{t})$, its production in 2010 declined to 2020 033t, e.g. by $39.71 \%$ (FAO). This has resulted in lower number of sheep, especially from merino breeds. The global trends, along the political and economic changes in the country had a negative impact on Bulgarian sheep farming. The number of sheep sharply decreased, leading to change in breeds and populations. The processes affected seriously merino breeds whose small population classified them as "endangered" (Aboneev et al., 2015). They are prerequisite for uniting the national merino breeds along with preservation of the breed type (Panayotov and Dimitrov, 2000) and implementation of a new model of selection combining good maturity and meat traits, optimum wool production, high yield and good wool technological properties (Slavov and Dimitrov, 2001). In 2011, a General breeding programme of merino sheep in Bulgaria for 20112020 of Association for breeding of fine-fleece sheep in Bulgaria (ABFFSB) was adopted (Boykovski et al., 2011), and in 2013 they are declared endangered from extinction and receive subsidy for conservation and maintenance.

The selection of merino sheep is aimed at increasing the productivity, in particular wool production and improvement of physico-mechanical properties of wool, e.g. technological properties (Slavova et al., 2016). As breed is a dynamical structure that is variable, the level of traits should be registered and analysed with respect to their maintenance or improvement.

Technological traits of wool from Bulgarian merino sheep breeds have been performed by Stankov (1985), Dimitrov (19941995), Tsenkova et al. (1995), Mihaylova et al. (1996), Slavova
(2000), Chincheva (2000), lliev (2002), Stefanova et al. (2005), Staikova and Stancheva (2009, 2010, 2013), Stancheva et al. (2015), etc.

The selection of rams, being carriers of genetic progress, is essential for modern programmes of selection (Tsenkova et al., 1995). One of sources providing information for evaluation of breeders is their own productivity. The aim of the study was to determine the levels of main selection traits determining technological properties of Caucasian ram wool.

\section{Material and methods}

The study was performed with rams from the Caucasian breed - a valuable part of the National gene pool and one of primary improving breeds for national merino sheep farming. It was conducted in 2009-2011 on 144 Caucasian rams owned by Kabiuk state enterprise - Shumen, reared and fed uniformly.

For determination of wool fineness, 252 wool samples from 126 animals were analysed. The samples were collected during the appraisal from two topographic areas: side and leg, in line with the instruction for control of production traits and appraisal of sheep (2003). The thickness of fibres was measured with Dorner's lanameter at the wool laboratory of the Selection Center of Animal Breeding in Shumen. Two hundred fibres were examined from all samples. Laboratory analysis of the wool natural length and crimp was done on 36 samples (from side and leg) of 18 rams (11 male lambs and 7 rams at 2.5 years of age). Samples were obtained at the time of appraisal; wool had grown for 10 months in male lambs (sheared as yearling rams) and for 11 month in rams. Wool length was measured with precision of $0.5 \mathrm{~cm}$. Wool crimp was determined in 10 areas through the number of crimps along $1 \mathrm{~cm}$.

Statistical analysis of data was done with Statistica 06 software.

\footnotetext{
*e-mail: dpamukova@uni-sz.bg
} 


\section{Results and discussion}

One of the most important features of wool from the point of view of its price and use as textile is the fineness (Hunter, 1993). For merino wool with average fibre thickness of $19.5-25.0 \mu \mathrm{m}, 70 \%$ of the price is formed by fineness (AWEX). Average fibre diameter is the main factor determining spinning traits, yarn and textile properties (Hunter, 1993; Khan et al., 2012). It varies both between breeds of a given productive type, as well as within the breed (Shotaev, 1978). Wool fineness is also influenced by some environmental factors as feeding and physiological condition (Brawn and Crook, 2005). The average fibre diameter has a substantial effect on the thickness and length of yarn. According to Dzhaparidze (1983) about $80 \%$ of variation of yarn thickness depends on ununiformity of fibres' thickness and only $15-20 \%$ depends on ununiformity of length.

The results of wool fineness analysis are presented in Table 1.
The average fibre diameter on the side was $21.98 \mu \mathrm{m}$, and varied between $21.71 \mu \mathrm{m}$ in 2010 to $22.30 \mu \mathrm{m}$ in 2009 . The differences between the years are minimum (from 0.26 to $0.59 \mu \mathrm{m}$ ) and statistically insignificant except that between 2009 and 2010 $(p<0.01)$. The leg wool fineness was similar to that of the side. Average fibre diameter was $23.05 \mu \mathrm{m}$ with max-min range of $23.34 \mu \mathrm{m}-22.76 \mu \mathrm{m}$. The differences in this trait's values over the years varied from 0.28 to $0.58 \mu \mathrm{m}$ but again, only the difference between 2009 and 2010 was significant $(p<0.01)$. Coefficients of variation (CV) were 12.3-14.00\%, indicating good staple uniformity of the wool of both topographic areas. According to the year of study, the differences between the leg and the side were minor - from 1.04 to $1.09 \mu \mathrm{m}$, e.g. $<2 \mu \mathrm{m}$, indicating food topographic uniformity. Therefore, as wool fineness was regarded, studied male lambs exhibited a good staple and topographic uniformity of wool fibres, a prerequisite for production of fine and quality merino yarn.

Table 1. Wool fineness on the side and the leg at 18 months of age, $\mu \mathrm{m}$

\begin{tabular}{|c|c|c|c|c|c|c|}
\hline \multirow{2}{*}{ Year } & \multicolumn{3}{|c|}{ Side } & \multicolumn{3}{|c|}{ Leg } \\
\hline & $n$ & Mean \pm SEM & $\mathrm{CV}, \%$ & $\mathrm{n}$ & Mean \pm SEM & $C V, \%$ \\
\hline 2009 & 31 & $22.30 \pm 0.183^{\mathrm{ac}}$ & 12.30 & 31 & $23.34 \pm 0.187^{b c}$ & 13.47 \\
\hline 2010 & 35 & $21.71 \pm 0.215^{\mathrm{ad}}$ & 12.74 & 35 & $22.76 \pm 0.201^{\mathrm{bd}}$ & 14.00 \\
\hline 2011 & 60 & $21.97 \pm 0.100^{\circ}$ & 13.20 & 60 & $23.06 \pm 0.100^{\circ}$ & 13.93 \\
\hline Total & 126 & $21.98 \pm 0.090$ & 12.85 & 126 & $23.05 \pm 0.087$ & 13.84 \\
\hline
\end{tabular}

* vertically: $a, b-p<0.01$; horizontally: $c, d, e-p<0.001$

Somewhat lower fineness values were established by Boykovski et al. (2003) - 21.28 $\mu \mathrm{m}$ on the side and 22.66 $\mu \mathrm{m}$ on the leg and Stefanova (2005) - $21.36 \mu \mathrm{m}$ and $22.55 \mu \mathrm{m}$, respectively in the Caucasian sheep breed. In the same breed, the authors reported a range of variation of the trait between $18.10 \mu \mathrm{m}$ and $25.20 \mu \mathrm{m}$ (Boykovski et al., 2009). The results of Slavov (2007) in male NorthEast Bulgarian Finewool sheep and its crosses with Australian merino sheep were comparable. The average fibre diameter in purebred animal was $22.13 \mu \mathrm{m}$ (side) and $23.05 \mu \mathrm{m}$ (leg), and in $1 / 2$ and $1 / 4$ blood crosses: $21.62-21.80 \mu \mathrm{m}$ and $22.59-22.79 \mu \mathrm{m}$. In imported Australian merino rams, average fibre thickness was $23.91 \mu \mathrm{m}$ (range $18.88 \mu \mathrm{m}$ to $25.80 \mu \mathrm{m}$ ) (Todorova et al., 1994).

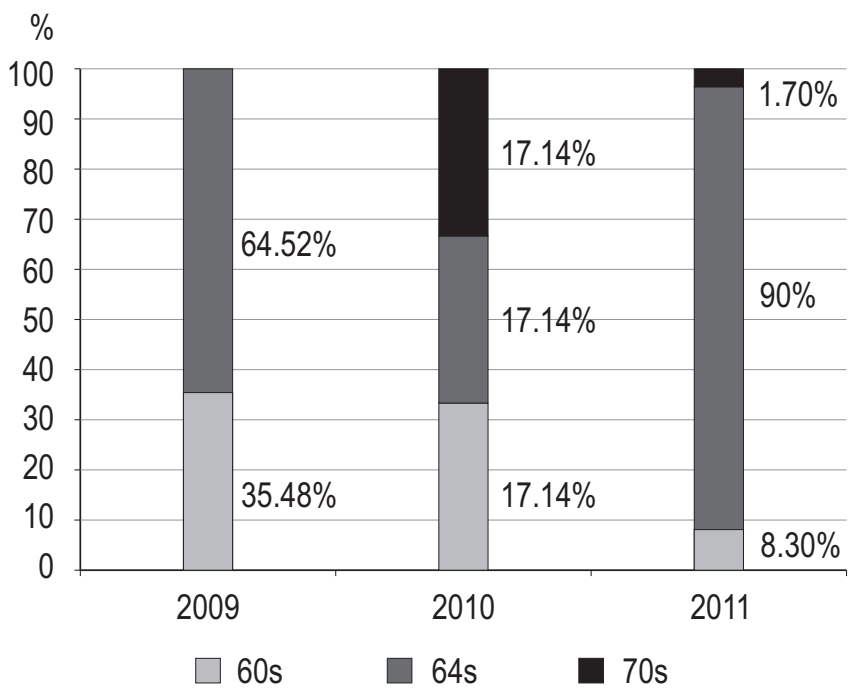

Figure 1. Distribution of animals by side wool quality in accordance with Bradford system
Results obtained show that wool fineness corresponded to grade 60 s to 70 s by the Bradford system (Figure 1). According to the year of study, animals with grade $64 \mathrm{~s}$ of side wool prevailed with a trend towards increase in its relative proportion from $64.52 \%$ in 2009 to $90 \%$ in 2011 . According to the Trade classification, wool with fineness grade $64 \mathrm{~s}$ and $70 \mathrm{~s}$ is classified and purchased as fine merino. On the leg, wool was mainly from grades $64 \mathrm{~s}$ and $60 \mathrm{~s}$ (Figure 2).

The selection in merino sheep breeds should be directed to typisation of the wool and improvement of topographic uniformity of the fleece (Panayotov, 1987). In this connection, Muhamegdaliev et al. (1984) claim that wool is considered uniform if the fleece contains

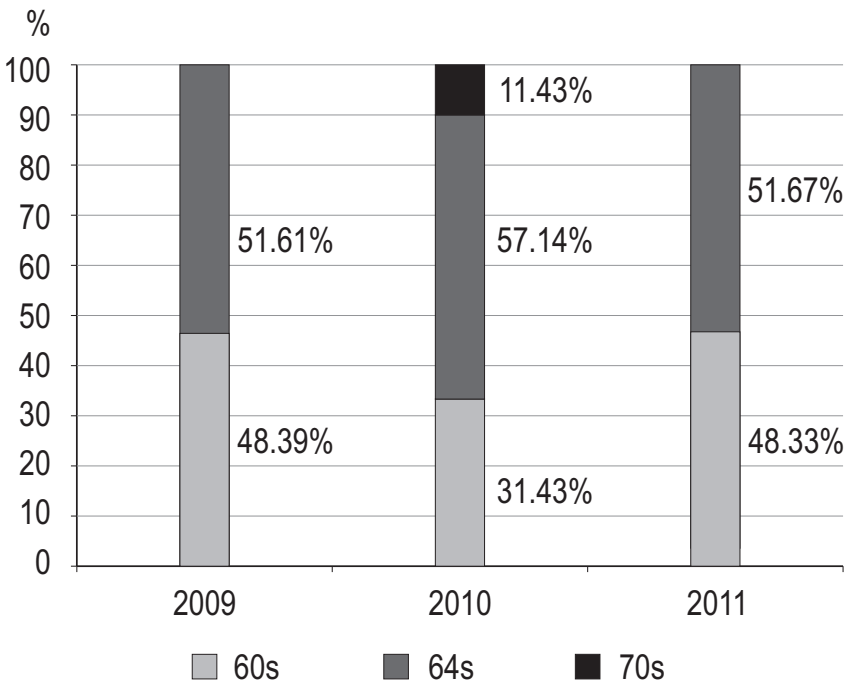

Figure 2. Distribution of animals by leg wool quality in accordance with Bradford system 
no more than 2-3 grades. The average relative proportion of male lambs with the same quality of side and leg wool was $76.98 \%$ (Table 2). From a total of 126 studied male lambs, in 29 (23.02\%), wool fineness in both areas was from two adjacent grades. According to the results, the studied sample was characterised with good topographic uniformity of wool fineness.

Table 2. Distribution of animals according to the number of quality grades of the fleece

\begin{tabular}{lrrrrr}
\hline \hline \multirow{2}{*}{ Year } & & \multicolumn{2}{c}{ with 1 grade } & \multicolumn{2}{c}{ with 2 grade } \\
\cline { 3 - 6 } & & $\mathrm{n}$ & $\%$ & $\mathrm{n}$ & $\%$ \\
\hline 2009 & 31 & 27 & 87.10 & 4 & 12.90 \\
2010 & 35 & 30 & 85.71 & 5 & 14.29 \\
2011 & 60 & 40 & 66.67 & 20 & 33.33 \\
Total & 126 & 97 & 76.98 & 29 & 23.02 \\
\hline \hline
\end{tabular}

The second important trait influencing the price, processing type of wool in textile industry and yarn properties is the natural length of wool (Hunter, 1993). This trait depends on a number of factors: age, feeding, physiological state, season, shearing, etc. The selection of wool-type sheep breeding is aimed at a good staple and topographic uniformity of fibres along their length which is essential during wool processing.

Data from laboratory analysis showed that the natural wool length of rams is average $7.57 \mathrm{~cm}$ on the side and $7.14 \mathrm{~cm}$ on the leg (for 11 month growth) and in male lambs $-6.86 \mathrm{~cm}$ and $6.05 \mathrm{~cm}$ (for 10 month growth), respectively (Table 3 ). In male lambs, leg wool was statistically significantly shorter $(P<0.05)$ that of the side.

Table 3. Natural wool length according to the category and topographic areas, $\mathrm{cm}$

\begin{tabular}{lrrrrrr}
\hline \hline \multirow{2}{*}{ Category } & \multicolumn{4}{c}{ Side } & \multicolumn{4}{c}{ Leg } \\
\cline { 2 - 7 } & $\mathrm{n}$ & Mean \pm SEM & CV, \% & $\mathrm{n}$ & Mean \pm SEM & CV, \% \\
\hline Rams & 7 & $7.57 \pm 0.561$ & 19.60 & 7 & $7.14 \pm 0.404$ & 14.97 \\
Male lambs & 11 & $6.86 \pm 0.145^{\mathrm{b}}$ & 12.80 & 11 & $6.05 \pm 0.196^{\mathrm{b}}$ & 10.76 \\
\hline \hline
\end{tabular}

* horizontally: $b-p<0.01$

According to the Trade classification (Bulgarian State Standard-BSS 507-88), the wool of rams and male lambs fulfilled the minimum requirements for first-class.

In Thracian finewool rams, the natural wool length varied within 9.59-9.90cm (Boykovski et al. 2009), and in imported Australian merino rams $-10.48 \mathrm{~cm}$ (Todorova et al., 1994). In North-East Bulgarian Finewool sires, natural wool length was on the average $10.93 \mathrm{~cm}$ in rams and $10.61 \mathrm{~cm}$ in male lambs (Slavov, 2007).

The crimp of wool contributes to preservation of its physicomechanical properties and influenced its technological processing. It is important for wool softness and volume, and is also among the traits characterising wool type (Slavov, 2007).

In the present study, the average number of crimps per 1 linear $\mathrm{cm}$ in rams was 5.07 (side) and 4.46 (leg), while in male lambs: 5.26 and 4.82 respectively (Table 4). The differences between groups 0.19 and 0.36 were not statistically significant. With regard to the category, the differences between the areas were small (0.61 in rams and 0.44 in male lambs) and insignificant.

Our results were higher that values reported by Todorova et al. (1994) in Australian merino rams (3.32 crimps per $1 \mathrm{~cm}$ ) but lower
Table 4. Wool crimp number on the side and leg at 18 months and 2.5 years of age

\begin{tabular}{|c|c|c|c|c|c|c|}
\hline \multirow{2}{*}{ Category } & \multicolumn{3}{|c|}{ Side } & \multicolumn{3}{|c|}{ Leg } \\
\hline & $n$ & Mean \pm SEM & CV, \% & $n$ & Mean \pm SEM & $C V, \%$ \\
\hline Rams & 70 & $5.07 \pm 0.444$ & 23.15 & 70 & $4.46 \pm 0.259$ & 15.37 \\
\hline Male lambs & 110 & $5.26 \pm 0.096$ & 11.06 & 110 & $4.82 \pm 0.204$ & 14.04 \\
\hline
\end{tabular}

* horizontally: $\mathrm{b}-\mathrm{p}<0.01$

than crimps established by Slavov (2007) in North-East Bulgarian Finewool rams and male lambs ( 5.72 and 5.56 for the side and 5.48 and 5.30 for the leg) and in rams with $1 / 2$ and $1 / 4$ Australian merino blood (5.88 and 5.78: side; 5.87 and 5.72: leg).

\section{Conclusion}

Caucasian rams exhibited a very good topographic uniformity of wool with respect to wool fibre diameter and natural length. The fineness of wool in the fleece was mainly from grade $64 \mathrm{~s}$ by the Bradford system, which characterised it as a fine merino wool. According to the year of study, animals with grade $64 \mathrm{~s}$ of side wool increase in its relative proportion from $64.52 \%$ in 2009 to $90 \%$ in 2011 . On the leg, wool was mainly from grades $64 \mathrm{~s}(51.61-51.57 \%)$ and 60 s (48.39-48.33\%). Studied animals were outlined with good topographic uniformity with regard to wool crimp. The average crimp number per $1 \mathrm{~cm}$ in rams was 5.07 on the side and 4.46 on the leg, while respective values in male lambs were 5.26 and 4.82 .

\section{Aknowledgements}

The publishing of the present scientific paper is co-financed by "Scientific Researches" Fund Contract No. 01/31 from 17.08.2017.

\section{References}

Aboneev V, Erohin A, Zhirjakov A, Lushnikov V and Jakovlenko A, 2015. The current status and prospects of the gene pool of fine wool sheep in Russia, Sheep, goats, woolen business, 1, 44-48 (Ru).

AWEX http://www.awex.com.au/media/1693/wool-bying-in australia-2014.pdf

Boykovski S, Stefanova G and Dimitrov D, 2003. Caucasian finewool sheep breed in Bulgaria, Shumen, p. 190 (Bg).

Boykovski S, Stefanova G and Stancheva N, 2009. Chemical composition, technically and technologically properties on the sheep wool. Shumen, p. 297 (Bg).

Boykovski S, Georgiev D, Slavov R, Slavova P, Iliev M and Tsonev T, 2011. Breeding program of Merino and Finewool sheep in Bulgaria for the period 2011-2020. Shumen, p. $25(\mathrm{Bg})$.

Brown DJ and Crook BJ, 2005. Environmental responsiveness of fibre diameter in grazing fine wool Merino sheep. Australian Journal of Agriculture Research, 56, 673-684.

Chincheva G, 2000. Investigation the effect of some genetic and non-genetic factors on the main productive traits of sheep from North-East Bulgarian Finewool Breed (Shumen type) Cucasian breed. Thesis for PhD, Sofia, Bulgaria $(\mathrm{Bg})$.

Dzhaparidze T, Zarytovskij V, Veniaminov A, Tiginejshvili N, 
Zheltobryuh N, Efremov A, Sidortsov V, Terebilenko N, Timashev I, Chevrenko I, Shugay E and Yashunin V, 1983. Sheepbreeding, Moscow, Kolos Publ. House (Ru).

Dimitrov I, 1994-1995. Determination the breeding value on finewool rams by selection indexes on estimation of their progeny. Genetics and Selection, 3-4, 137-143 (Bg).

Hunter L, 1993. Mohair: A Review of its Properties, Processing and Application, CSIR, Port Elizabeth, Republic of South Africa, p. 286.

Iliev M, 2002. Influence the line on the productivity on male rams from the Karnobat finewool sheep breed. Journal of Animal Science, 6, 30-32(Bg).

Instruction for control of production traits and appraisal of sheep, 2003. Ministry of agriculture and forestry, Executive Agency on Selection and Reproduction in Animal Breeding. Sofia, Kontrast Publ. House $(\mathrm{Bg})$.

Mihaylova L, Lazarov V and lliev M, 1996. The relative importance of wool components for Karnobat fine wool sheep. Journal of Animal Science, 3, 9-12(Bg).

Khan M J, Abbas A, Ayaz M, Naeem M, Akhter MS and Soomro MH, 2012. Factors affecting wool quality and quantity in sheep. African Journal of Biotechnology, 11, 13761-13766.

Muhamedgaliev F, Bekzhanv S and Doboryanov N, 1984. Creation of new types finewool sheep in Kazakhstan, Alma-Ata (Ru). Panayotov D, 1987. Investigation on Topographic equalizing of the fleece according to fineness for Thracian fine-wool sheep. Journal of Animal Science, 11, 31-37 (Bg).

Panayotov D and Dimitrov I, 2000. State and directions for the development of fine-fleece sheep breeding in Bulgaria. ABFFSB (Materials for constituent assembly), Sofia $(\mathrm{Bg})$.

Shotaev A, 1978. Inheritance of physicomechanical properties of wool of crossbred sheep, Genetic bases of ontogenesis and selection of animals. Alma-Ata, pp. 13-19 (Ru).

Slavov R and Dimitrov I, 2001. Study on effect of breed proportion in crossing North-Bulgarian fine wool sheep with Australian merino rams I. Basic selection traits. Journal of Animal Science, 2, 13-16 (Bg).

Slavov R, 2007. Opportunities for improvement of sheep from North-East Bulgarian Finewool Breed - Dobrudzha type. Thesis for
DSc, Stara Zagora, Bulgaria $(\mathrm{Bg})$.

Slavova P, 2000. Study on phisyc-mechanical characteristics of wool from ewes of Tracian fine-wool breed and their crosses with Australian merino rams. Journal of Animal Science, 1, 5-10 (Bg).

Slavova P, Dimitrov I, Laleva St and Popova Y, 2016. Study of dynamics in variation of wool production in sheep of Thracian fine fleece breed. Journal of Animal Science, 3-6, 52-58 (Bg).

Staikova G and Stancheva N, 2009. Effect of some factors on the wool yield and staple length at different ages in sheep from the Northeast Bulgarian Fine Fleece Breed - Shumen type. Bulgarian Journal of Agricultural Science, 15, 5, 463-470 (Bg).

Staikova $\mathbf{G}$ and Stancheva N, 2010. Effect of different sources of specific variability on live weight and wool production traits in Ascanian ewes. Journal of Animal Science, 5, 22-31 (Bg).

Staikova G and Stancheva N, 2013. Effect of different sources of specific variance on traits of wool productiveness in caucasian merino breed. Journal of Animal Science, 6, 47-55 (Bg).

Stankov I, 1985. Investigation on the quantity and some qualitative indicators of the wool of the pure-bred Caucasian and North Caucasian sheep and their crosses. Journal of Animal Sciences, 11, $27-31(\mathrm{Bg})$.

Stancheva N, Slavova P, Laleva St, Krustanov Zh, lliev M, Staikova G, Kalaydzhiev G and Tzonev T, 2015. Present status, development and productivity of bulgarian fine-fleece sheep breeds in some herds of Agricultural academy. Journal of Animal Science, 5, 62-71 (Bg).

Stefanova G, Boykovski S, Stancheva N and Dimitrov D, 2005. Sources of specific variance and inheritance of yield, pure fiber, staple length and fiber diameter of sheep from Caucasian breed. Coll. International Scientific Conference, Stara Zagora, Veterinary Medicine, Animal Husbandry, 4, 56-61 (Bg).

Todorova L, Raicheva E and Petrova I, 1994. Phenotype characteristic of wool properties of rams from Australian merino breed. Journal of Animal Science, 5-6, 37-39 (Bg).

Tsenkova I, Tsenkov I and Slavova P, 1995. Wool productivity and wool characteristics in fine wool rams from the herd of Research Institute for Cattle and Sheep Prduction - Stara Zagora. Journal of Animal Science, 3-4, 95-101 (Bg). 


\section{Genetics and Breeding}

Variation in the agronomic and morphological traits in spring barley

N. Dyulgerov, B. Dyulgerova

Study on the loss of accuracy of AC method for milk yield control in sheep

D. Dimov, P. Zhelyazkova, A. Vuchkov

Hordein polymorphism between spring barley cultivars by SDS-PAGE electrophoresis

N. Neykov, S. Doneva

\section{Nutrition and Physiology}

Comparative study of rapeseed, monofloral types and multifloral honey by some physico-chemical parameters

I. Zhelyazkova, S. Lazarov

Body condition score, nonesterified fatty acids and beta-hydroxybutyrate concentrations in goats with subclinical ketosis

V. Marutsova, R. Binev

\section{Production Systems}

Lucrative status of improved dual purpose cowpea (Vigna unguiculata L., Walp) in Damboa, Borno State, North-Eastern Nigeria

B.H. Gabdo

Study on the emptying time of grain harvester hoppers

K. Trendafilov, N. Delchev, B. Kolev, G. Tihanov

Length of the growing season and yield in Triticum monococcum L., in accordance with the growing conditions

S. Stamatov, E. Valchinova, G. Desheva, K. Uzundzhalieva, P. Chavdarov, T. Cholakov, B. Kyosev, R.

Ruseva, N. Velcheva

Productivity of durum wheat cultivar Predel at nitrogen-phosphorous fertilization

L. Plescuta

Effect of the herbicide treatment dose on the weed infestation in common winter wheat

Z. Petrova

Evaluation of some technological properties of Caucasian ram wool

D. Pamukova, G. Staykova, N. Stancheva, D. Panayotov 


\section{Agriculture and Environment}

Saved $\mathrm{CO}_{2}$ emissions by using renewable sources for hot water yield in Bulgarian dairy farms

R. Georgiev, R. Slavov, K. Peychev, D. Georgiev, S. Apostolov, J. Ellingsen, J. Tønnesen

Inventory of the legal base for reclamation of lands disturbed by open-cast mining in Bulgaria

M. Banov, V. Tzolova, I. Kirilov

Taxonomic composition of phytoplankton in Black Sea area in front of the Cape Galata (2008-2016)

D. Klisarova, D. Gerdzhikov

Biodiversity of the macrozoobenthos in some protected marine areas along Bulgarian Black Sea coast

E. Petrova, S. Stoykov

Heavy metals in organs of gudgeon (Gobio gobio L.) from Vardar River, R. Macedonia

R. Nastova, V. Kostov, I. Uslinovska

Product Quality and Safety

Mathematical methods for assessment and analysis of honey yield data for Bulgaria and the

N. Keranova

Carcass traits and meat quality of different slow growing and fast growing broiler chickens

M. Oblakova, N. Mincheva, P. Hristakieva, I. Ivanova, M. Lalev, Sv. Georgieva

Role and importance of the awareness for whey in dairy sector at an international level 


\section{Instruction for authors}

\section{Preparation of papers}

Papers shall be submitted at the editorial office typed on standard typing pages (A4, 30 lines per page, 62 characters per line). The editors recommend up to 15 pages for full research paper ( including abstract references, tables, figures and other appendices)

The manuscript should be structured as follows: Title, Names of authors and affiliation address, Abstract, List of keywords, Introduction, Material and methods, Results, Discussion, Conclusion, Acknowledgements (if any), References, Tables, Figures.

The title needs to be as concise and informative about the nature of research. It should be written with small letter /bold, 14/ without any abbreviations.

Names and affiliation of authors The names of the authors should be presented from the initials of first names followed by the family names. The complete address and name of the institution should be stated next. The affiliation of authors are designated by different signs. For the author who is going to be corresponding by the editorial board and readers, an E-mail address and telephone number should be presented as footnote on the first page. Corresponding author is indicated with *

Abstract should be not more than 350 words. It should be clearly stated what new findings have been made in the course of research. Abbreviations and references to authors are inadmissible in the summary. It should be understandable without having read the paper and should be in one paragraph.

Keywords: Up to maximum of 5 keywords should be selected not repeating the title but giving the essence of study.

The introduction must answer the following questions: What is known and what is new on the studied issue? What necessitated the research problem, described in the paper? What is your hypothesis and goal?

Material and methods: The objects of research, organization of experiments, chemical analyses, statistical and other methods and conditions applied for the experiments should be described in detail. A criterion of sufficient information is to be possible for others to repeat the experiment in order to verify results.

Results are presented in understandable tables and figures, accompanied by the statistical parameters needed for the evaluation. Data from tables and figures should not be repeated in the text. Tables should be as simple and as few as possible. Each table should have its own explanatory title and to be typed on a separate page. They should be outside the main body of the text and an indication should be given where it should be inserted.

Figures should be sharp with good contrast and rendition. Graphic materials should be preferred. Photographs to be appropriate for printing. Illustrations are supplied in colour as an exception after special agreement with the editorial board and possible payment of extra costs. The figures are to be each in a single file and their location should be given within the text.

Discussion: The objective of this section is to indicate the scientific significance of the study. By comparing the results and conclusions of other scientists the contribution of the study for expanding or modifying existing knowledge is pointed out clearly and convincingly to the reader. Conclusion: The most important consequences for the science and practice resulting from the conducted research should be summarized in a few sentences. The conclusions shouldn't be numbered and no new paragraphs be used. Contributions are the core of conclusions. References:

In the text, references should be cited as follows: single author: Sandberg (2002); two authors: Andersson and Georges (2004); more than two authors: Andersson et al.(2003). When several references are cited simultaneously, they should be ranked by chronological order e.g.: (Sandberg, 2002; Andersson et al., 2003; Andersson and Georges, 2004).

References are arranged alphabetically by the name of the first author. If an author is cited more than once, first his individual publications are given ranked by year, then come publications with one co-author, two co-authors, etc. The names of authors, article and journal titles in the Cyrillic or alphabet different from Latin, should be transliterated into Latin and article titles should be translated into English. The original language of articles and books translated into English is indicated in parenthesis after the bibliographic reference $($ Bulgarian $=\mathrm{Bg}$, Russian $=\mathrm{Ru}$, Serbian $=\mathrm{Sr}$, if in the Cyrillic, Mongolian =
Mo, Greek = Gr, Georgian = Geor., Japanese $=\mathrm{Ja}$, Chinese $=\mathrm{Ch}$, Arabic $=\mathrm{Ar}$, etc.)

The following order in the reference list is recommended:

Journal articles: Author(s) surname and initials, year. Title. Full title of the journal, volume, pages. Example:

Simm G, Lewis RM, Grundy B and Dingwall WS, 2002. Responses to selection for lean growth in sheep. Animal Science, 74, 39-50

Books: Author(s) surname and initials, year. Title. Edition, name of publisher, place of publication. Example:

Oldenbroek JK, 1999. Genebanks and the conservation of farm animal genetic resources, Second edition. DLO Institute for Animal Science and Health, Netherlands.

Book chapter or conference proceedings: Author(s) surname and initials, year. Title. In: Title of the book or of the proceedings followed by the editor(s), volume, pages. Name of publisher, place of publication. Example:

Mauff G, Pulverer G, Operkuch W, Hummel K and Hidden C, 1995. C3variants and diverse phenotypes of unconverted and converted C3. In: Provides of the Biological Fluids (ed. $\mathrm{H}$. Peters), vol. 22, 143-165, Pergamon Press. Oxford, UK.

Todorov N and Mitev J, 1995. Effect of level of feeding during dry period, and body condition score on reproductive performance in dairy cows, IX $X^{\text {th }}$ International Conference on Production Diseases in Farm Animals, September 11-14, Berlin, Germany.

Thesis:

Hristova D, 2013. Investigation on genetic diversity in local sheep breeds using DNA markers. Thesis for PhD, Trakia University, Stara Zagora, Bulgaria, (Bg).

The Editorial Board of the Journal is not responsible for incorrect quotes of reference sources and the relevant violations of copyrights.

\section{Animal welfare}

Studies performed on experimental animals should be carried out according to internationally recognized guidelines for animal welfare. That should be clearly described in the respective section "Material and methods". 


\section{AGRICULTURAL \\ SCIENCE AND TECHNOLOGY}

Volume 9, Number 4 December 2017
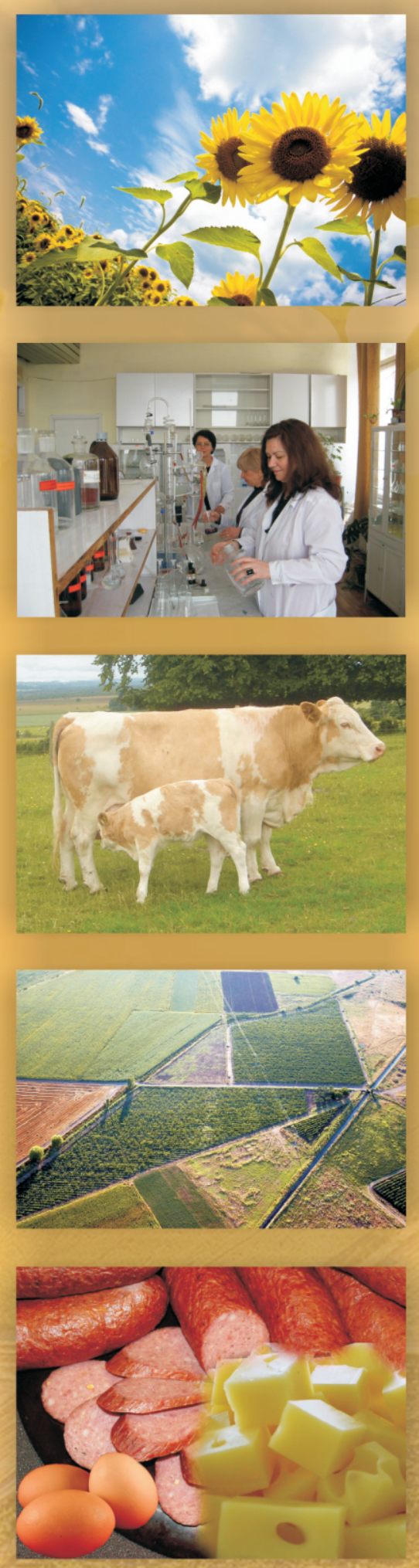

Journal web site: 